\title{
Assessment of rabex-5 level of thyroid nodules with benign and malignant characteristics in aspiration cytology
}

\section{Aspirasyon sitolojisinde benign ve malign özellik taşıyan tiroid nodüllerinin RABEKS 5 düzeyinin değerlendirilmesi}

\author{
Barıș Sarıakçalı', Güllhan Dumann ${ }^{1}$, Sevtap Bakır ${ }^{2}$
}

Sivas Cumhuriyet University Medical Faculty Departmant of Internal Medicine, Sivas, Turkey

${ }^{2}$ Sivas Cumhuriyet University Medical Faculty Departmant of Medical Biochemistry, Sivas, Turkey

Corresponding author: Barış Sarıakçalı, MD, Sivas Cumhuriyet University Medical Faculty Departmant of Internal Medicine, Sivas, Turkey

E-mail: drbbarissariakcali@gmail.com

Received/Accepted: December 23,2019/December 31,2019

Conflict of interest: There is not a conflict of interest.

\section{SUMMARY}

Objective: The aim of the present study was to determine the Rabex-5 level in the plasma of patients who were found to have benign and malignant cytology as a result of fine-needle aspiration biopsy implemented on thyroid nodules and to determine whether there was a difference between benign and malignant.

Method: The cytology of 117 benign and 26 malignant thyroid nodules was evaluated as the study material.

Results: It was determined that the nodule diameter had no effect on benign and malignant cytology ( $p$ 0.998). There was no significant difference found between age and benign and malignant cytology results ( $p$ 0.591). There was no difference between female and male genders in terms of Rabex-5 level ( $\mathrm{p}$ 0.654).

Conclusions: In conclusion, it was found that there was no difference in plasma RABEX-5 levels of patients with benign and malignant thyroid nodule cytology. However, it is thought that further studies to evaluate the expression of Rabex-5 in cancerous tissues of patients with thyroid malignancies will provide a scientific contribution

Keywords: Thyroid, nodule, rabex, cytology
(iD) Barış Sarıkçalı
(D) Gülhan Duman
(D) Sevtap Bakır

ORCID IDs of the authors: B.S. 0000-0001-5133-1318 G.D. $0000-0002-4057-5701$ S.B. 0000-0003-1956-0844

\section{ÖZET}

Amaç: Sunulan çalışmada tiroid nodüllerine yapılan ince iğne aspirasyon biyopsisi ile, sitoloji sonucu bening ve maling çıkan hastaların plazmalarında Rabeks 5 düzeyleri ölçülerek, bening ve maling arasında bir farkın olup olmadığının saptanması amaçlanmıştır.

Yöntem: Çalışma materyali olarak 117 bening ve 26 malign tiroid nodül sitolojisi değerlendirildi.

Bulgular: Çalışma sonunda nodul çapının bening ve maling sitoloji üzerine etkisi bulunmadı (p 0.998). Hastaların yaş değerinin bening ve maling sitoloji sonuçlarıyla ilişkisinde fark saptanmadı ( $\mathrm{p} 0,591)$. Rabex 5 düzeyi ile kadın ve erkek cinsiyet arasinda fark bulunmadi ( $\mathrm{p} 0,654)$.

Sonuç: Benign ve maling tiroid nodül sitolojisi olan hastaların plazmasında RABEX-5 düzeyinde fark saptanmadı. Fakat tiroid malignitesi olan hastaların, kanserli dokularından yapılabilecek Rabeks 5 ekpresyonunu değerlendiren yeni çalışmaların bilimsel katkısının olacağı düşünülmektedir.

Anahtar sözcükler: Tiroid, nodül, rabeks, sitoloji 


\section{INTRODUCTION}

Thyroid nodules are defined as shaped lesions with distinguishable boundaries that occupy a place in the thyroid gland and differ from the surrounding thyroid tissue. Iodine deficiency is known as the most common cause of nodule formation. The frequency of nodules has been reported to increase with age ${ }^{1,4} .4 .7 \%$ of solitary thyroid nodules are considered to be malignant. If the nodule is hypoechoic, has irregular boundaries, involves micro-calcification, and has a height longer than its width, the risk of malignancy increases. Fine-needle aspiration biopsy is a common and easy method implemented for thyroid nodules ${ }^{1}$.

Endocytosis and exocytosis are the main functions that cells utilize to maintain their normal physiological functions. In the cell, GTPases play an important role in signal transduction, endocytosis, and vesicle transport. In addition, they are involved in the regulation and differentiation of cell growth. In the Ras family, there are more than 50 GTPase species including Rab. Rabex-5 is a GTPase in the Rab family that is involved in intracellular signal transduction and endocytosis and in the regulation and differentiation of cell growth ${ }^{2}$.

In recent studies, the expression level of Rabex-5 has been shown to be significantly high in many cancers that are breast, prostate, and colorectal cancers. It is suggested that this abnormal expression in tumors has an important role in the pathogenesis and progression of cancer ${ }^{5,6}$.

In this study, the Rabex-5 level in the plasma of patients who were found to have benign and malignant cytology as a result of fine-needle aspiration biopsy implemented on thyroid nodules was measured and the difference between benign and malignant was investigated.

\section{MATERIAL AND METHODS}

A total of 127 patients, 98 female and 29 male, with benign thyroid nodule cytology and a total of 26 patients, 18 female and 7 male, with malignant cytology were included in the study (Written / oral confirmation was obtained from people who participated in the study). Patients with inadequate, type "A" cytology outcome and with suspected follicular neoplasia were excluded from the study. $5 \mathrm{ml}$ of blood was collected from the patients into the routine biochemistry tubes; the blood samples were centrifuged at 4000rpm for 10 minutes and aliquoted into Eppendorf tubes and stored at $-80 \mathrm{C}$ for determination of serum Rabex5 levels. Serum Rabex-5 levels were determined through the ELISA method using the Mybiosource kit. The analytical sensitivity of the kit is $0.1 \mathrm{ng} / \mathrm{ml}$. Statistical evaluation of the data obtained in our study was achieved using the SPSS 22 software.

\section{RESULTS}

In the study, TSH level, diameter, number, and Rabex 5 level of benign and malignant nodules, and correlation with age and gender were analyzed (Table 2). TSH level was found to be higher in malignant nodules (p 0.005, Graphic 2). Benign cytology results were determined to be significantly higher in patients with a higher number of nodules ( $\mathrm{p} 0.001$, Graphic 1). It was found that the diameter of the nodule had no effect on benign and malignant cytology ( $p$ 0.998). There was no significant difference determined between the age and benign and malignant cytology results (p 0.591). There was no significant difference found between Rabex-5 level and male and female genders ( $p$ 0.654). There was no significant difference found between Rabex-5 level and benign and malignant nodules and the levels were similar to each other (p 0.149). The number of patients with benign and malignant cytology and their distribution according to gender were presented in (Table 1). 
Table 1: The number of patients with benign and malignant cytology and their distribution according to gender

\begin{tabular}{|l|l|r|r|c|}
\hline \multirow{2}{*}{ Gender } & \multirow{2}{*}{ Statistics } & \multicolumn{2}{|c|}{ benign.malignant } & \multirow{2}{*}{$\mathrm{p}$} \\
\cline { 3 - 4 } & & benign & malignan & \\
\hline \multirow{2}{*}{ Female } & $\mathrm{n}$ & 98 & 18 & \\
\cline { 2 - 4 } & $\%$ & $84.5 \%$ & $15.5 \%$ & \multirow{2}{*}{0.579} \\
\hline \multirow{2}{*}{ Mzle } & $\mathrm{n}$ & 29 & 7 & \\
\cline { 2 - 4 } & $\%$ & $80.6 \%$ & $19.4 \%$ & \\
\hline
\end{tabular}

Table 2: TSH level, diameter, number, and Rabex 5 level of benign and malignant nodules, and correlation with age and gender

\begin{tabular}{|c|c|c|c|c|c|c|}
\hline Variable & Group & Minimum & Maximum & Mean & Standard Deviation & $p$ \\
\hline \multirow{2}{*}{ TSH } & benign & 0.00 & 8.96 & 1.71 & 1,59 & \multirow{2}{*}{0.005} \\
\hline & malignant & 0.04 & 5.81 & 2.44 & 1.42 & \\
\hline \multirow{2}{*}{ Nodule diam } & benign & 9.30 & 60.00 & 1932 & 9.24 & \multirow{2}{*}{0998} \\
\hline & malignant & 4.20 & 70.00 & 2248 & 16.52 & \\
\hline \multirow{2}{*}{ Number of $n$} & benign & 1.00 & 7.00 & 2.66 & 1.31 & \multirow{2}{*}{0001} \\
\hline & malignant & 1.00 & 7,00 & 1,92 & 1,41 & \\
\hline \multirow{2}{*}{ rabex } & benign & 0.50 & 16.20 & 3.93 & 5.49 & \multirow{2}{*}{0.149} \\
\hline & malignant & 0.60 & 10.00 & 4.12 & 3.28 & \\
\hline \multirow{2}{*}{ Age } & benign & 20.00 & 75,00 & 5188 & 13.36 & \multirow{2}{*}{0.591} \\
\hline & malignant & 200 & 85.00 & 5024 & 16.69 & \\
\hline & Gender & Minimum & Maximum & Mean & Standard Deviation & $p$ \\
\hline \multirow{2}{*}{ rabex } & female & 0.50 & 1620 & 5.46 & $4.7 \mathrm{~g}$ & \multirow{2}{*}{0654} \\
\hline & male & 0.70 & 14.20 & 3,42 & $5,1 \mathrm{~s}$ & \\
\hline
\end{tabular}

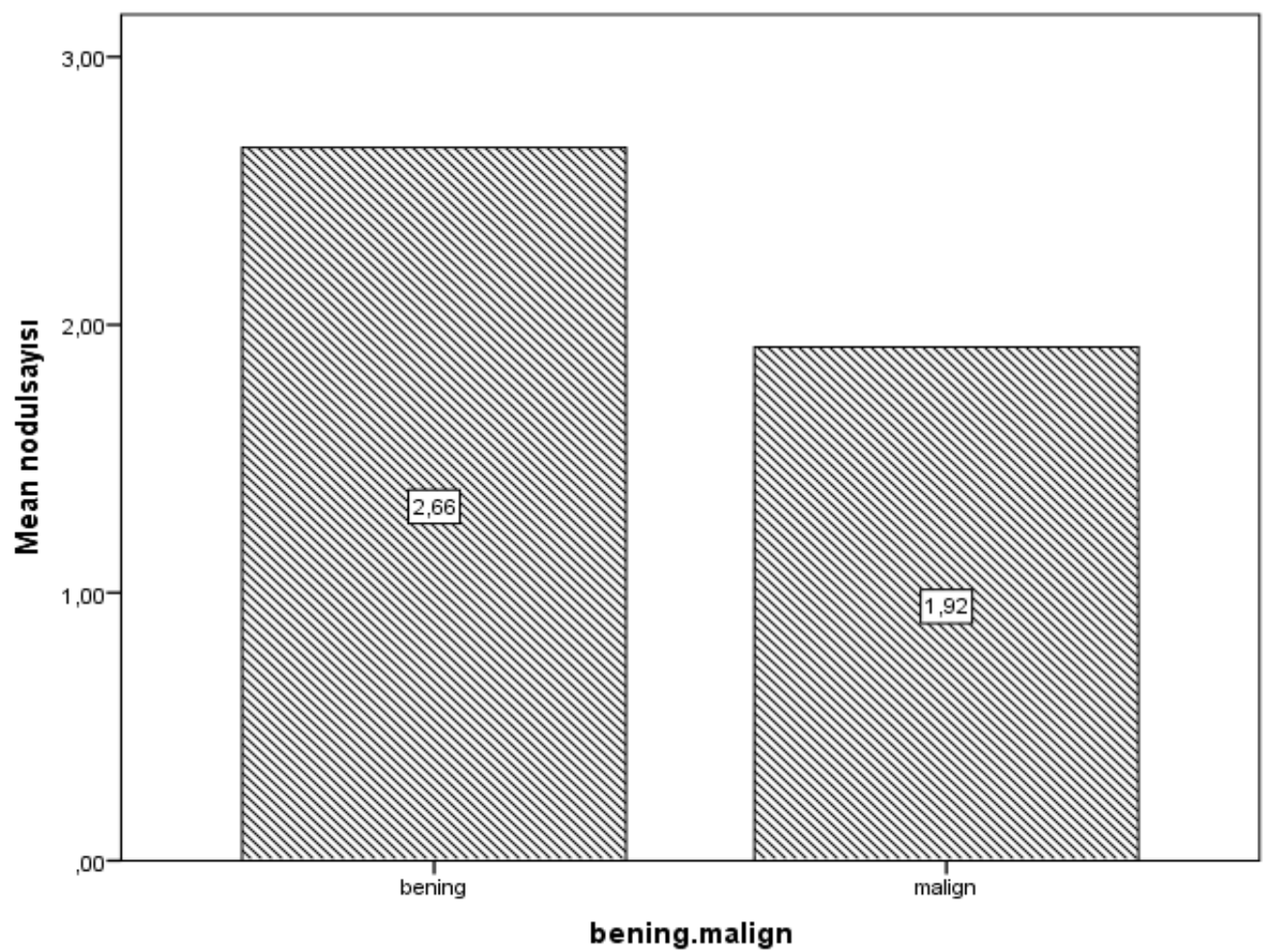

Graphic 1: (Mean number of nodules / benign and malignant) 


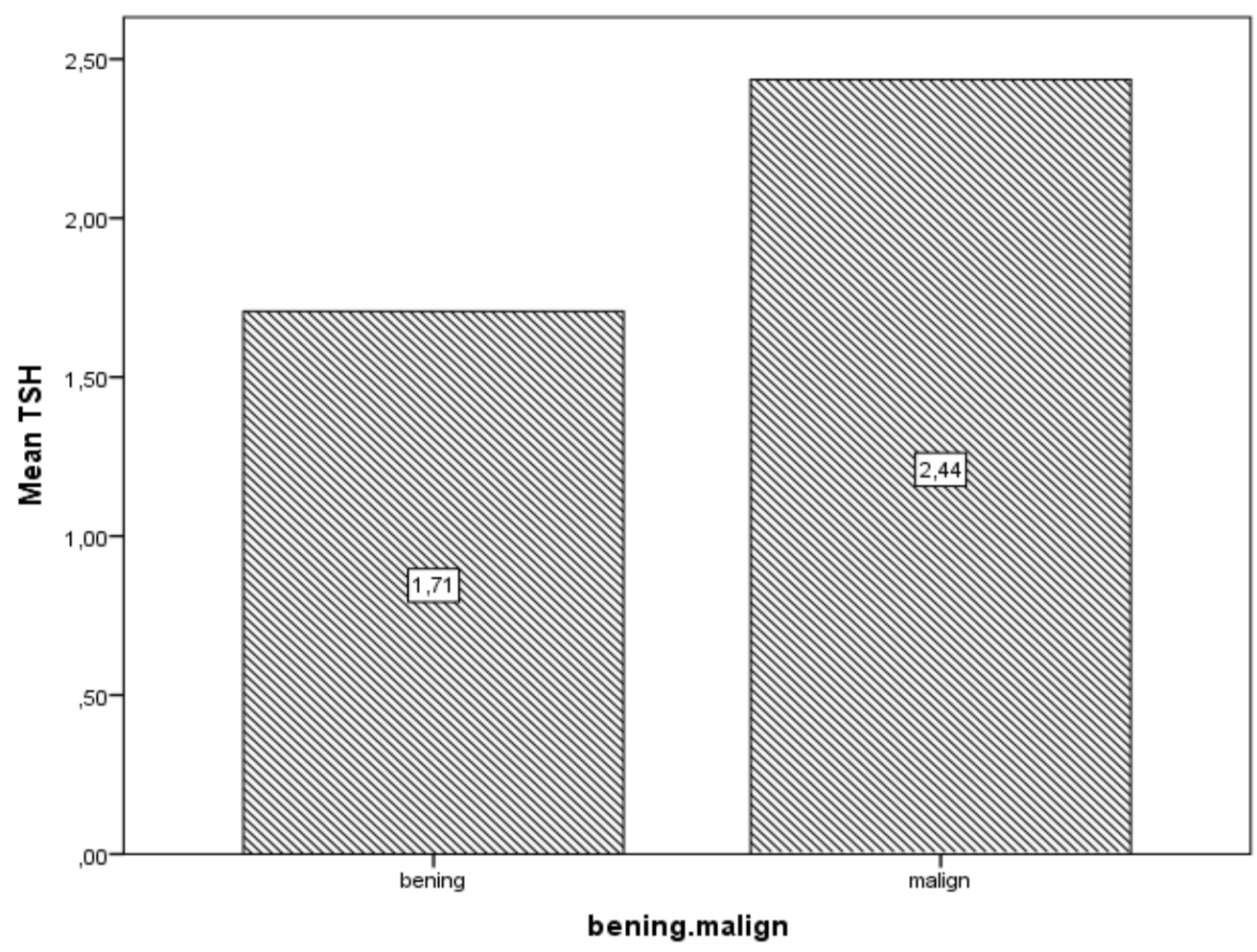

Graphic 2: (Mean level of TSH / benign and malignant)

\section{DISCUSSION}

In the cell, GTPases play an important role in signal transduction, endocytosis, and vesicle transport. Additionally, they are involved in the regulation and differentiation of cell growth. There are more than 50 GTPase species in the Ras family, including Rab. RABEX-5 is involved in the intracellular signal transduction, endocytosis, and regulation and differentiation of cell growth ${ }^{2}$.

In recent studies, the expression level of Rabex-5 has been shown to be significantly high in many cancers that are breast, prostate, and colorectal cancers. In this present study, we investigated whether the RABEX-5 level has a diagnostic and prognostic level in plasma of patients with benign and malignant thyroid nodule cytology. In the study conducted by J.S. ZHANG et al. ${ }^{5}$ to assess Rabex-5 expression in cancerous tissue and surrounding non-cancerous tissue in patients with colorectal cancer, it was found that the Rabex-5 expression was significantly higher in cancerous tissue. In addition, it was reported that high RABEX-5 expression reduced survival. Again, in the study conducted by kang $\mathrm{L}$ et al. ${ }^{6}$ to evaluate Rabex-5 expression in cancerous tissue and surrounding non-cancerous tissue in patients with gastric cancer, it was found that high Rabex-5 level was associated with invasion and metastasis of gastric cancer and poor survival. Similar findings were obtained by ZHANG $\mathrm{F}$ et al. ${ }^{7}$ in their study on lung cancer with small cells.

The difference of this study from previous similar studies is the measurement of only plasma Rabex5 levels. In this study, the plasma Rabex-5 levels of patients with benign and malignant thyroid nodule cytology as a result of fine-needle aspiration biopsy were measured and there was no difference found between them. This may be due to the measurement of plasma Rabex-5 level and the plasma Rabex-5 may not be increased in these benign and malignant nodules. Another reason may be that thyroid malignancy has better survival than other cancer types, that it is a benign tumor, and that its distant metastasis is very rare.

Although no difference was determined in the plasma Rabex-5 level in patients with benign and malignant thyroid nodule cytology in this study, we think that a study evaluating the expression of Rabex-5 in cancerous tissues of patients with thyroid malignancy would provide an important scientific contribution.

\section{CONCLUSION}

We did not find a difference in plasma Rabex-5 levels in 127 patients with benign thyroid nodule cytology and 26 patients with malignant thyroid nodule cytology. We did not find a difference between Rabex-5 level and gender. 
We found that the TSH level was higher in patients with malignant thyroid cytology. The number of nodules was higher in patients with benign thyroid cytology. We did not find a correlation between age and malignant and benign thyroid cytology.

\section{REFERENCES}

1. Vanderpump MP The Epidemiology of Thyroid Disease. Br Med Bull (2011).99:3951.

2. Ze Rial M, Mcbride H. Rab Proteins as Membrane Organizers. Nat Rev Mol Cell Biol (2001). 2: 107-117.

3. Erdoğan MF, Kamel N, Aras D, Akdoğan A, Başkal N, Erdoğan G. Value of Re-aspira Benign Nodular Thyroid Disease. Thyroid (1998).8:1087-90.
4. Bernards A, Settlema NJ. GAP Control: Regulating the Regulators of Small GTPases. Trends Cell Biol (2004). 14: 377-385.

5. Zhang JS, Yang LQ, Du Br, Gao H. Higher RABEX-5 mRNA Predicts Unfavourable Survival in Patients with Colorectal Cancer. Eur Rev Med Pharmacol Sci. (2017). 21(10):2372-2376.

6. Kang 1, Hao X, Tang Y, Wei X, Gong Y. RABEX-5 Overexpression in Gastric Cancer is Correlated with Elevated MMP-9 level. Am J Transl Res (2006). 8: 2365-2374.

7. Zhang F, Jia Y, Kong F, Hu G, Cai Q, Xu T. Elevated RABEX-5 Expression Predicts Poor Prognosis in Non-Small-Cell Lung Cancer. Am J Cancer Res (20015). 5: 2849-2855. 